๑) Open Access Full Text Article

CORRIGENDUM

\title{
Magnetic Targeting of HU-MSCs in the Treatment of Glucocorticoid-Associated Osteonecrosis of the Femoral Head Through Akt/Bcl2/Bad/Caspase-3 Pathway [Corrigendum]
}

Duan L, Zuo J, Zhang F, et al. Int J Nanomedicine. 2020;15:3605-3620.

The authors have advised Figure 9 on page 3618 is incorrect. An error was made during the preparation of images for part 9C. The correct Figure 9 is shown below.

The authors apologise for this error. 

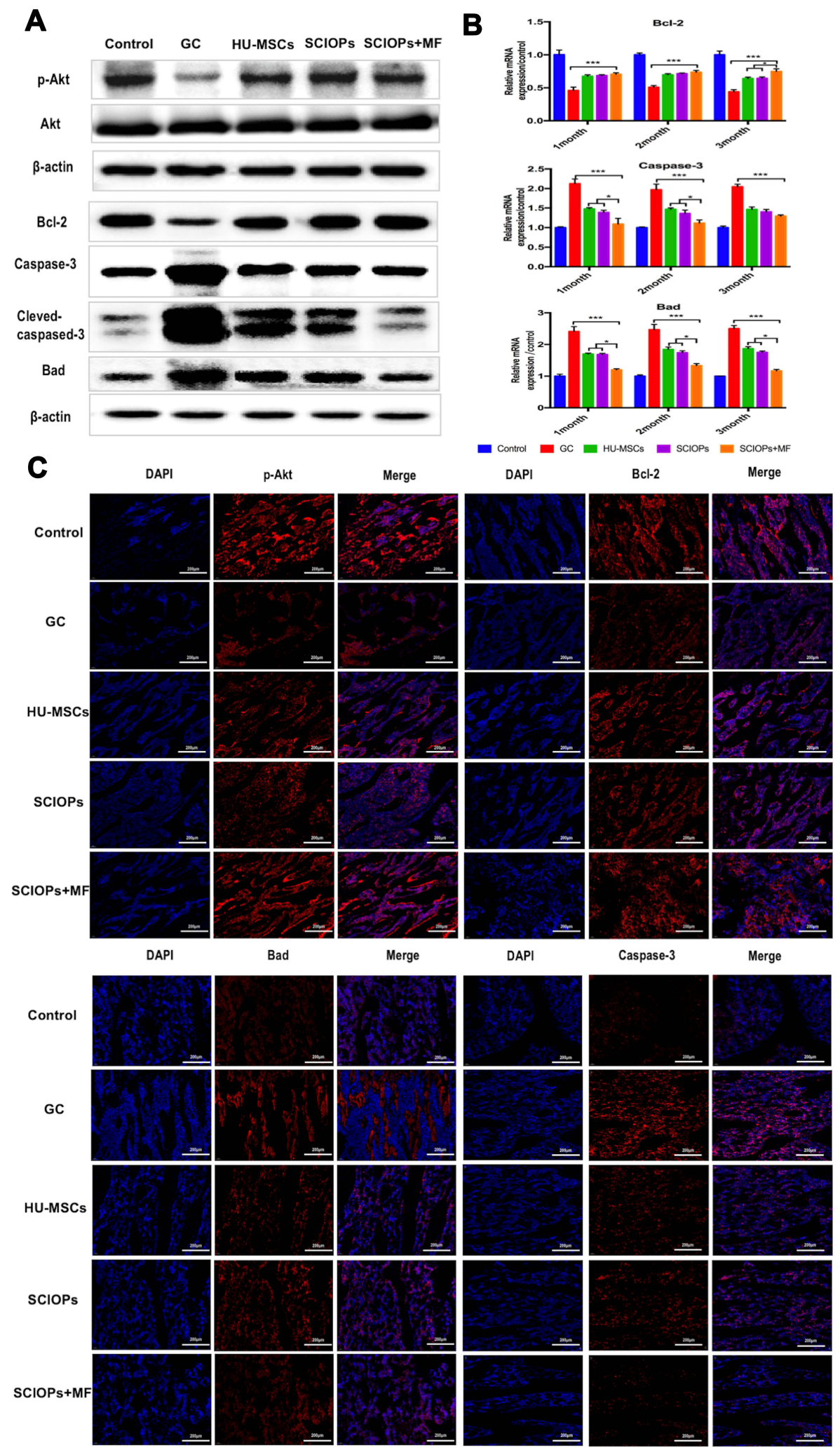

Figure 9 Expression levels of apoptosis proteins. (A) In the different treatment groups, the p-Akt Bcl-2, and Bad caspase-3 protein expression levels were examined by Western blotting. (B) In the different treatment groups, the BCl-2, Bad, and caspase-3 mRNA expression levels were examined by RT-PCR. Bar represents the SD, ****P $<0.00$ I, $* P<0.05$, vs the GC group. (C) The immunofluorescence indicated the expression level of p-Akt, Bcl-2, Bad, and caspase- 3 in the bone tissue from the different treatment groups (third month). Scale bar: $200 \mu \mathrm{m}$. 


\section{Publish your work in this journal}

The International Journal of Nanomedicine is an international, peerreviewed journal focusing on the application of nanotechnology in diagnostics, therapeutics, and drug delivery systems throughout the biomedical field. This journal is indexed on PubMed Central, MedLine, CAS, SciSearch ${ }^{\mathbb{B}}$, Current Contents ${ }^{\mathbb{B}} /$ Clinical Medicine,
Journal Citation Reports/Science Edition, EMBase, Scopus and the Elsevier Bibliographic databases. The manuscript management system is completely online and includes a very quick and fair peer-review system, which is all easy to use. Visit http://www.dovepress.com/ testimonials.php to read real quotes from published authors.

Submit your manuscript here: https://www.dovepress.com/international-journal-of-nanomedicine-journal 